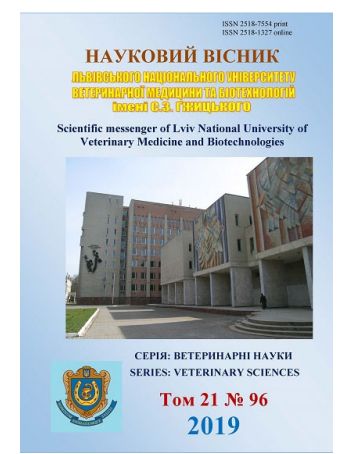

\author{
Науковий вісник Львівського національного університету \\ ветеринарної медицини та біотехнологій імені С.3. Гжицького. \\ Серія: Ветеринарні науки
}

Scientific Messenger of Lviv National University of Veterinary Medicine and Biotechnologies. Series: Veterinary sciences

\title{
Influence of medication "Membranostabil" on expression of immunoreceptor proteins in small intestine of ruminants during the period of formation of colostral immunity
}

\author{
S.I. Holopura, M.I. Tsvilikhovsky, B.V. Popadiuk \\ National University of Life and Environmental Sciences of Ukraine, Kyiv, Ukraine
}

Article info

Received 23.10.2019

Received in revised form 26.11.2019

Accepted 27.11.2019

National University of Life and Environmental Sciences of

Ukraine, Potekhina Str., 16 building 12, Kyiv, 03127,Ukraine Tel.: 8(067) 789-41-27 Tel.: 8(067) 238-05-36 Tel.: 8(098) 994-76-13 E-mail:golopura@ukr.net

E-mail:M_Tsvilikhovsky@ukr.net E-mail: bogdana144@gmail.com
Holopura, S.I., Tsvilikhovsky, M.I., \& Popadiuk, B.V. (2019). Influence of medication "Membranostabil" on expression of immunoreceptor proteins in small intestine of ruminants during the period of formation of colostral immunity. Scientific Messenger of Lviv National University of Veterinary Medicine and Biotechnologies. Series: Veterinary sciences, 21(96), 147-152. doi: $10.32718 /$ nvlvet 9626

The influence of medication "Membranostabil" on the indexes of content of proteins with MM of 33, 40 , and $47 \mathrm{kDa}$ in the plasmolemma of enterocytes of jejunum of new-born calves during the period from birth till the age of 24-hours was investigated. The research was conducted on calves (males) of Ukrainian black-and-white breed during the spring. Throughout the trial period, the calves of the control and experimental groups were kept on a standard diet for newborn calves, colostrum. In addition, calves of the experimental group got the medication "Membranostabil" based on the soybean lecithin. Proteins of plasmolemma of enterocytes of the jejunum of calves were isolated from the membrane fraction of lysates and examined by electrophoresis. Electrophoretic separation of proteins of plasmolemma of the jejunum enterocytes of newborn calves revealed proteins with MM of 37, 40 and $43 \mathrm{kDa}$ on electrophoregram. The data of expression of immunoreceptor proteins with MM of 37, 40, $43 \mathrm{kDa}$ and the dynamics of their changes depending on the time after birth in calves of the control and experimental groups were analyzed. The decrease in the total content of expression of proteins with MM of 37, 40, and $43 \mathrm{kDa}$ in the membrane fraction of lysates of enterocytes of the jejunum of calves at the age of 6 hours compared to the newborn ones was demonstrated. The levels of expression of each immunoreceptor protein are considered with their comparative analysis between the individual fractions in the cytolemma of the enterocytes of the jejunum of newborn calves, which according to their molecular weights correspond to MM isoforms of FcrRIII/CD32. The data obtained showed a significantly higher expression of level of proteins with molecular mass of $37 \mathrm{kDa}$ on the apical membrane of enterocytes, compared with proteins with MM of 40 and $43 \mathrm{kDa}$, both at birth of calves and at the age of 6 and 24 hours. Based on the data obtained, proteins with MM of 37, 40, and $43 \mathrm{kDa}$ of plasmolemma of the jejunum enterocytes undergo significant changes in the process of postnatal ontogeny in cattle. These changes indicate the synthesis of these proteins in the enterocytes themselves in the process of formation of colostral immunity in newborn calves under the influence of the medication "Membranostabil" used by this research group, compared with calves of the control group. It is shown that the application of medication "Membranostabil" for the new-born calves activates the transport of immunoglobulins of colostrum in the intestine of these animals, assists the increasing of level of colostral immunity, and prevents the occurrence of digestive disorders. Findings of this research correlate with the results of clinical observation in newborn calves.

Key words: new-born calves, jejunum, proteins of cytolemma of enterocytes, immunoglobulins, membranostabil, colostral immunity.

\section{Вплив препарату “Мембраностабіл” на експресію імунорецепторних білків у тонкому кишечнику жуйних у період формування колострального імунітету}

\author{
С.І. Голопура, М.І. Цвіліховський, Б.В. Попадюк
}




\section{Національний університет біоресурсів і природокористування Украӥни, м. Київ, Украӥна}

Досліджено вплив препарату “Мембраностабіл” на показники вмісту білків з молекулярними масами 37, 40 та 43 кДа у плазмолемі ентероцитів порожньої кишки новонароджених телят у період від їх народження $і$ до 24-годинного віку. Дослідження проводили на телятах (самиі) української чорно-рябої породи у весняний період року. Впродовж усього дослідного періоду телят контрольної та дослідної груп утримували на стандартному рачіоні для новонароджених телят - молозиві. Додатково телятам дослідної групи застосовували всередину препарат на основі соєвого лецитину “Мембраностабіл”. Білки плазмолеми ентероцитів порожньої кишки телят виділяли з мембранної фракиії лізатів і досліджували за допомогою електрофорезу. При електрофоретичному розділенні білків плазмолеми ентероцитів порожньої кишки новонароджених телят на електрофореграмі нами були виявлені білки з ММ 37, 40 та 43 кДа, Проаналізовані дані експресії імуноречепторних білків з ММ 37, 40, 43 кДа та динаміку їх змін залежно від часу після народження в телят контрольної та дослідної груп. Показане зменшення сумарного вмісту експресії білків з ММ 37, 40 та 43 кДа у мембранній фракиї̈ лізатів ентероцитів порожньої кишки телят у віці 6 годин порівняно з щойно новонародженими та відновлення їх рівня на 24-y годину їх життя. Розглянуті рівні експресії кожного з імунорецепторних білків з їх порівняльним аналізом між окремими фракиіями в плазмолемі ентероиитів порожньої кишки новонароджених телят, які за своїми молекулярними масами відповідають МM ізоформ FсүRIII/CD32. Одержані нами дані показали значно вищий рівень експресії білків з ММ 37 кДа на апікальній мембрані ентероцитів, порівняно з білками з ММ 40 i 43 кДа, як при народженні телят, так $і$ у віці 6 та 24 години. На основі отриманих нами даних білки з молекулярними масами 37, 40 та 43 кДа плазмолеми ентероцитів порожньої кишки великої рогатої худоби в процесі постнатального онтогенезу піддаються значним змінам. Ці зміни вказують на синтез иих білків у власне самих ентероцитах у процесі формування колострального імунітету в новонароджених телят під впливом застосованого нами препарату "Мембраностабіл", порівняно з телятами контрольної групи. Показано, що застосування новонародженим телятам препарату "Мембраностабіл” активізує транспорт імуноглобулінів молозива в кишечнику цих тварин, сприяє підвищенню рівня колострального імунітету й запобігає виникненню розладів травлення. Одержані нами дані корелюють із результатами клінічного спостереження за новонародженими телятами.

Ключові слова: новонароджені телята, порожня кишка, протеїни плазмолеми ентероцитів, імуноглобуліни, мембраностабіл, колостральний імунітет.

\section{Вступ}

Одним із факторів, що визначає формування колострального імунітету в новонароджених телят $\epsilon$ здатність ентероцитів тонкого кишечника ефективно адсорбувати імуноглобуліни (Ig) 3 молозива матері. Останнє визначається структурними можливостями плазмолеми ентероцитів у період новонародженості, а саме іiі ліпідним і білковим складом, в’язкістю, присутністю поліпептидних рецепторів Ig та активністю транспортних аденозинтрифосфатаз (Tsvilikhovskyi, 1998). У свою чергу, мікров'язкість клітинних мембран, яка регулюється співвідношенням насичених i ненасичених жирних кислот фосфоліпідів, залежить від вмісту вітаміну А в клітинних мембранах, а процеси окиснення мембранних ліпідів і їх оновлення в значній мірі залежать від вітаміна E (Suraj et al., 1997). Досить часто раціон корів у період тільності не збалансований за вітамінами, тому, новонароджені телята 3 молозивом не отримують необхідну їх кількість.

Так, наприклад, через дефіцит у молозиві вітаміну А у новонароджених телят порушується моторна, секреторна та всмоктувальна функції шлунковокишкового тракту через ороговіння слизових оболонок і в перші доби життя у телят виникає захворювання на диспепсію (Bondi, 1987).

Проведеними нами раніше дослідженнями (Holopura et al., 2017) показано, що застосування новонародженим телятам макрокапсул з фосфоліпідного бішару на основі соєвого лецитину активує транспорт Ig у тонкому кишечнику цих тварин у період формування колострального імунітету, що сприяє підвищенню його рівня. Ідея цієї роботи полягала у застосуванні новонародженим телятам у період формування колострального імунітету макрокапсул із фосфоліпідного бішару, наповнених водорозчинними формами вітамінів А і Е.
Мета і завдання дослідження. Виходячи з означеного вище метою роботи було дослідити показники вмісту імунорецепторних білків у плазмолемі ентероцитів порожньої кишки новонароджених телят у період формування колострального імунітету при застосуванні 3 молозивом розробленого нами препарату „Мембраностабіл”. Завдання дослідження - проаналізувати динаміку білків з ММ 37, 40 та 43 кДа при електрофоретичному розділенні їх в плазмолемі ентероцитів порожньої кишки новонароджених телят за впливу на тварин препарату “Мембраностабіл”.

\section{Матеріал і методи досліджень}

Дослідження проводились в НДГ “Великоснітинське ім. О.В. Музиченка” НУБіП України на новонароджених телятах чорно- рябої породи в період від народження до досягнення 1-добового віку. Було сформовано контрольну та дослідну групи телят, по 6 тварин у кожній. Телятам обох груп випоювали молозиво - 2 л після народження, а потім по 1,5 л через кожні 6 год впродовж першої доби життя тварин. Телята контрольної групи отримували лише молозиво. Телятам дослідної групи перед першим випоюванням молозива застосовували всередину створений нами на основі соєвого лецитину препарат "Мембраностабіл" у дозі 5 мл 3 теплою водою $\left(37^{\circ} \mathrm{C}\right)$ в об’ємі 50 мл. Препарат “Мембраностабіл” являє собою макрокапсули 3 фосфоліпідного бішару, які наповнені водорозчинними формами вітамінів А $-4000 \mathrm{MO}$ і Е - 15 мг (патент на корисну модель № 92841 від 10.09.2014 p., Бюл. № 17 (Tsvilikhovskyi et al., 2014).

Дослідні зразки ентероцитів порожньої кишки відбирали від новонароджених телят до першої випойки молозива та через 6 і 24 години після народження тварин. За виконання експериментальних досліджень на новонароджених телятах було дотримано всіх біое- 
тичних вимог у відношенні до тварин, що відповідають Закону України "Про захист тварин від жорстокого поводження” (стаття 17) від 28.03.2017 р., “Свропейській конвенції на захист хребетних тварин” від 13.11.1987 р. та Регламенту Ради (СС) № 1099/2009 від 24 вересня 2009 року.

Ентероцити отримували за допомогою хімічного (цитрат/ЕДТО) методу (Tsvilikhovskyi, 1998). Із ентероцитів спочатку виділяли апікальні та базолатеральні мембрани за схемою описаною Цвіліховським М.I. (Tsvilikhovskyi, 1998).

Дослідження вмісту протеїнів у плазмолемі ентероцитів порожньої кишки новонароджених телят проводили шляхом електрофоретичного розділення в 7,5\% поліакриламідному гелі з натрію додецилсульфатом за модифікованою методикою 3 додаванням трицину (Schägger \& von Jagow, 1987). У діапазоні від 30 до 50 кДа, нами було виявлено ряд протеїнів, у т.ч. 3 молекулярними масами (ММ) 37, 40 та 43 кДа. Відсотковий вміст фракцій протеїнів визначали методом денситометрії з використанням програмного забезпечення TotalLab.

Статистичну обробку результатів досліджень проводили 3 використанням комп'ютерної програми Microsoft Excel 2003.

\section{Результати та їх обговорення}

При електрофоретичному розділенні білків плазмолеми ентероцитів порожньої кишки новонароджених телят на електрофореграмі нами були виявлені білки з МM 37, 40 та 43 кДа, що відповідають рецепторам FcyRIII/CD32. Функція цих білків полягає у зв'язуванні IgG молозива в просвіті кишечника і забезпеченні однонаправленого їх транспорту через плазмолему ентероцитів у кров тварин у нативному (незміненому) вигляді (Jones \& Waldman, 1972; Masiuk \& Tsvilikhovskyi, 2011).

Одержані нами дані показали значно вищий рівень експресії білків з ММ 37 кДа на апікальній мембрані ентероцитів, порівняно з білками з ММ 40 і 43 кДа, як при народженні телят, так і у віці 6 та 24 години (рис. 1).

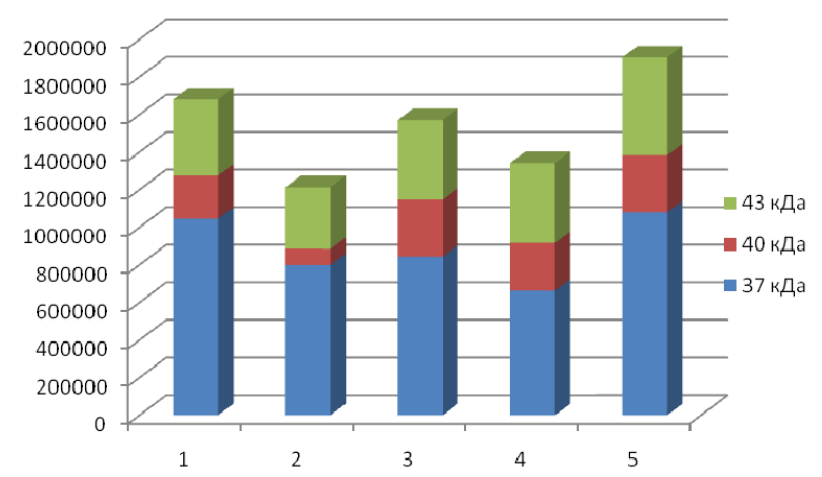

Рис. 1. Рівень експресії імунорецепторних білків на плазмолемі ентероцитів порожньої кишки телят після народження та у віці 6-у і 24-у години: 1 - телята до випойки молозива; 2 і 3 - контроль - 6 та 24 години, відповідно; 4 і 5 - дослід - 6 та 24 години, відповідно
Результати дослідження експресії білків з ММ 37, 40 та 43 кДа у мембранній фракції лізатів ентероцитів порожньої кишки телят при народжені вказують на відносно високий їх вміст (рис. 1.1), що свідчить про готовність цих білків до рецепції Ig молозива та транспортування їх у нативному стані через ентероцити в кровоносне русло.

Після випоювання молозива спостерігається зниження експресії білків з ММ 37, 40 та 43 кДа у плазмолемі ентероцитів порожньої кишки новонароджених телят контрольної групи у віці 6 годин на 27,8\% $(\mathrm{P} \leq 0,01)$ (рис. 1.2). Це свідчить про інтенсивне всмоктування Ig молозива та їх транспорт у кишечнику тварин за механізмом Ig-рецептор через ентероцит від його апікальної (АМ) до базолатеральної (БМ) мембрани і далі - в кров тварини. У той же час, відновлення рівня білків з ММ 37, 40 і 43 кДа у плазмолемі ентероцитів телят на 24-у годину їх життя (рис. 1.3) вказує на їх ретранспорт від БМ до АМ для послідуючого здійснення рецепції Ig молозива.

У плазмолемі ентероцитів порожньої кишки телят дослідної групи, яким застосували препарат "Мембраностабіл", нами встановлено зниження на 20,1\% (P $\leq$ 0,05) експресії білків з ММ 37, 40 та 43 кДа у віці 6 годин та підвищення на 13,3\% у віці 24 години порівняно з цим показником у телят при народженні (див. рис. 1.4 і 1.5).

Одержані дані вказують на те, що препарат "Мембраностабіл" активує експресію імунорецепторних білків з ММ 37, 40 та 43 кДа на плазмолемі ентероцитів порожньої кишки новонароджених телят у період формування колострального імунітету. Таким чином, вітаміни А і Е у складі ліпосом стабілізують імунорецепторні білки плазмолеми ентероцитів, що забезпечують трансмембранний транспорт колостральних імуноглобулінів із просвіту кишечника в кровоносне русло новонароджених телят.

Одержані нами дані корелюють із результатами клінічного спостереження за новонародженими телятами.

Так, на другу добу життя у 2-х із 5-ти телят контрольної групи з'являлися ознаки розладу травлення. Апетит у тварин знижувався, смоктальний рефлекс був пригніченим, перистальтика кишечника посилювалася, дефекація часта, кал розріджений, світложовтого кольору. У телят навколо ануса досить швидко з'явилися забруднення каловими масами. Температура тіла у телят контрольної групи на початку захворювання була в межах норми, а 3 розвитком хвороби температура шкіри на окремих місцях знижувалась: нижні ділянки кінцівок, вуха, носове дзеркальце - холодні.

Телята дослідної групи через 24 години після народження були активними, ознак діареї в них не спостерігалося. Кал світлого жовто-коричневого кольору. В однієї тварини спостерігалися незначні розлади травлення після застосування препарату "Мембраностабіл”, але на наступну добу вони зникли без медикаментозного втручання. Впродовж всього послідуючого періоду дослідження телята дослідної групи були 
активними, ознак розладів травлення та виснаження у них не спостерігалося.

Отримані нами дані узгоджуються з результатами, що були отримані іншими дослідниками (Kurtiak \& Yanovych, 2004). Ними встановлено, що майже весь ретинол у клітинних мембранах міцно зв'язується 3 білками і лише незначна його кількість звільняється при екстракції ліпідів. При цьому разом з ретинолом у клітинних мембранах була виявлена ретиноєва кислота, яка міцно зв'язана 3 їх компонентами. На основі цих даних було зроблено припущення, що з ретинолом пов'язана структурна і транспортна функції клітинних мембран (Kurtiak \& Yanovych, 2004). Крім того, вітамін А і його похідні діють на специфічні рецепторні білки в клітинних ядрах. У подальшому такий ліганд-рецепторний комплекс зв'язується 3 ділянками ДНК і викликає дерепресію генів, регулюючи синтез білків, ферментів або компонентів тканин (Morozkina \& Mojsejonok, 2002; Kurtiak \& Yanovych, 2004).

Вважаємо за доцільне розглянути рівні експресії кожного з імунорецепторних білків плазмолеми ентероцитів порожньої кишки новонароджених телят, які за своїми молекулярними масами відповідають ММ ізоформ Fc $\gamma$ RIII/CD32.

Одержані нами дані свідчать про високий вміст білка з ММ 37 кДа в плазмолемі ентероцитів порожньої кишки новонароджених телят, а також про те, що вміст цього білка в мембрані значно змінюється в процесі формування колострального імунітету в цих тварин (рис. 2).

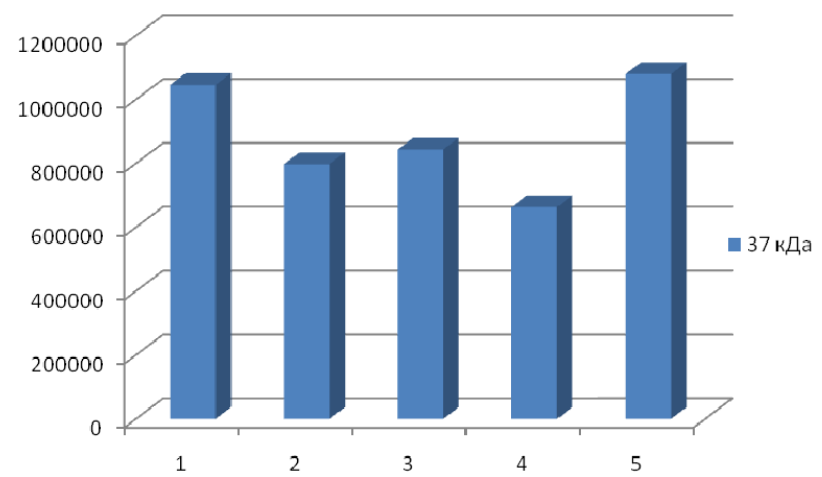

Рис. 2. Рівень експресії імунорецепторних білків 3 молекулярною масою 37 кДа на плазмолемі ентероцитів порожньої кишки телят при народженні та на 6-у і 24-у години їх життя: 1 - телята до випойки молозива; 2 і 3 - контроль - 6 та 24 години, відповідно; 4 і 5 - дослід - 6 та 24 години, відповідно

Так, через 6 годин після народження концентрація білка з ММ 37 кДа у плазмолемі ентероцитів порожньої кишки телят контрольної групи достовірно знижується в 1,24 раза (P $\leq 0,01)$, а в телят дослідної групи - в 1,40 раза $(\mathrm{P} \leq 0,001)$. Це вказує на активну участь білка з МM 37 кДа у транспорті Ig молозива в період формування колострального імунітету в новонароджених телят і на те, що цей процес $є$ більш інтенсивним під впливом застосованого нами препарату “Мембраностабіл".
Концентрація білка з ММ 37 кДа в плазмолемі ентероцитів порожньої кишки телят контрольної групи на 24-у годину їх життя не змінилася, тоді як у телят дослідної групи достовірно зросла в 1,63 раза $(\mathrm{P} \leq 0,001)$ (рис. 2.2 і 2.4). При цьому різниця в експресії на плазмолемі ентероцитів білка з ММ 37 кДа на 24-у годину життя тварин між телятами контрольної і дослідної групи склала 28\% на користь останньої (рис. 2.3 і 2.5). Отримані нами результати є підтвердженням більш активного трансмембранного перенесення комплексу імуноглобулін/рецептор, а також більш швидкого відновлення плазмолеми ентероцитів та ретранспорту імунорецепторного білка 3 МM 37 кДа від БМ до АМ для послідуючого перенесення Ig молозива в кров, що відбувається під впливом препарату “Мембраностабіл” у телят дослідної групи порівняно з контрольною.

Результати проведених нами досліджень свідчать про більш, ніж у 4 рази менший вміст білка з ММ 40 кДа в плазмолемі ентероцитів новонароджених телят, порівняно з білком з ММ 37 кДа (див. рис. 1).

Рівень експресії білків з ММ 40 кДа на плазмолемі ентероцитів порожньої кишки новонароджених телят контрольної групи у віці 6 годин знизився на майже в 3 рази, $(\mathrm{P} \leq 0,001)$ порівняно з цим показником у телят при народженні (рис. 3; 3.1 і 3.2).

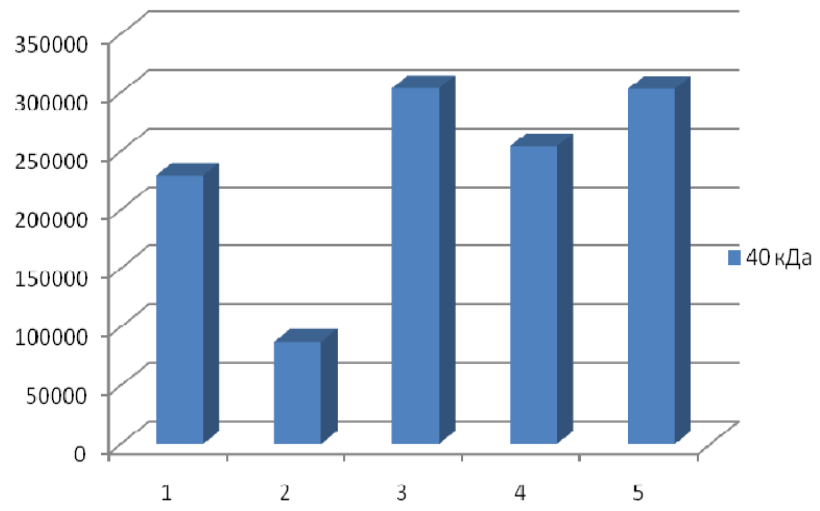

Рис. 3. Рівень експресії імунорецепторних білків 3 молекулярною масою 40 кДа на плазмолемі ентероцитів порожньої кишки телят при народженні та на 6-у і 24-у години їх життя: 1 - телята до випойки молозива; 2 і

3 - контроль - 6 та 24 години, відповідно; 4 і 5 - дослід 6 та, 24 години, відповідно

Це є закономірним явищем з огляду на найбільш інтенсивне всмоктування Ig молозива в кишечнику новонароджених тварин у перші 6 годин їх життя. В той же час, ретранспорт білків з ММ 40 кДа плазмолеми ентероцитів порожньої кишки новонароджених телят контрольної групи з БМ до АМ затримується і відновлюється тільки на 24 годину життя цих тварин (рис. 3.2 і 3.3), чого не спостерігається у телят дослідної групи під впливом препарату "Мембраностабіл" (рис. 3.4. і 3.5).

Так, рівень експресії білків з ММ 40 кДа на плазмолемі ентероцитів порожньої кишки новонароджених телят дослідної групи, яким застосовували препарат "Мембраностабіл", є вищим на 10,9\% (P $\leq 0,05)$ та 
32,3\% (P $\leq 0,01)$ у віці 6 і 24 години, відповідно, порівняно $з$ таким при народженні (див. рис. 3 ; 3.4 і 3.5 ).

Рівень експресії білків з ММ 43 кДа на плазмолемі ентероцитів порожньої кишки новонароджених телят контрольної групи був достовірно нижчим на 19\% $(\mathrm{P} \leq 0,01)$ у віці 6 годин і повертався до вихідного рівня у віці 24 години порівняно $з$ таким у телят при народженні (рис. 4; 4.2 і 4.3).

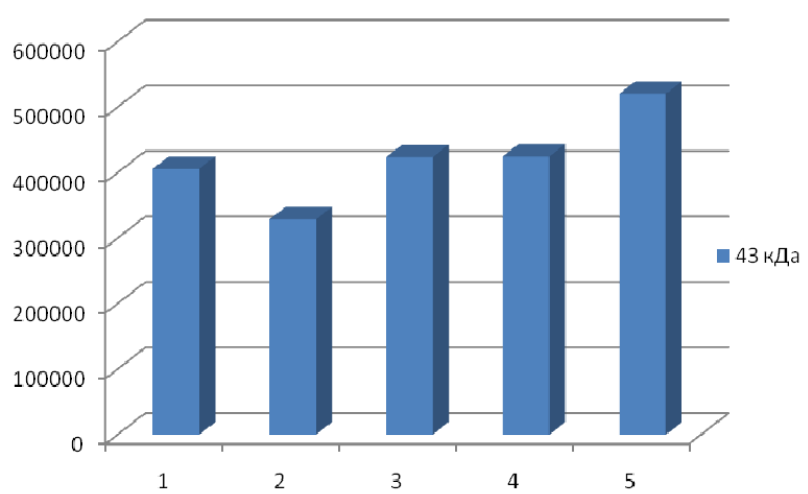

Рис. 4. Рівень експресії імунорецепторних білків 3 молекулярною масою 43 кДа на плазмолемі ентероцитів порожньої кишки телят при народженні та на 6-у і 24-у години їх життя: 1 - телята до випойки молозива; 2 i 3 - контроль - 6 та 24 години, відповідно; 4 і 5 - дослід - 6 та, 24 години, відповідно

Рівень експресії білків з ММ 43 кДа у плазмолемі ентероцитів порожньої кишки телят дослідної групи залишався стабільним на 6-ту годину життя цих тварин та достовірно підвищувався $28,3 \%(\mathrm{P} \leq 0,01)$ у віці 24 години порівняно 3 таким у телят при народженні (рис. 4; 4.4 і 4.5). Останнє може бути свідченням активного синтезу цих білків у власне самих ентероцитах у процесі формування колострального імунітету в новонароджених телят під впливом застосованого нами препарату “Мембраностабіл", оскільки на 24-у годину життя телят дослідної групи вміст у плазмолемі ентероцитів порожньої кишки білка з ММ 43 кДа був на 22,9\% достовірно вищим $(\mathrm{P} \leq 0,01)$ порівняно $з$ телятами контрольної групи (рис. $4 ; 4.3$ і 4.5).

Таким чином, білки плазмолеми ентероцитів порожньої кишки новонароджених телят з ММ 37, 40 та 43 кДа володіють імунорецепторною активністю по відношенню до Ig молозива і беруть активну участь у формуванні колострального імунітету. Вміст цих білків і їх активність у плазмолемі ентероцитів тонкого кишечника $\epsilon$ визначальним фактором рівня колострального імунітету в організмі новонароджених телят для становлення якого відводиться обмежений час (24-36 годин). Можливо й час перебування колостральних Ig у крові телят, до моменту включення їх власної імунної системи, також обумовлюється їх зв'язком 3 імунорецепторними білками плазмолеми ентероцитів. Останні (частково) можуть транспортуватися у кров теляти у зв'язаному вигляді з Ig молозива в складі комплексу Ig-рецептор (Tsvilikhovskyi, 1998) і вони здатні пролонгувати період колостраль- ного імунітету та здійснювати захист організму телят від дії сторонніх, у т.ч. патогенних чинників. Це підтверджується отриманими нами раніше даними щодо молекулярних механізмів формування колострального імунітету у великої рогатої худоби (Maryniuk et al., 2014; Holopura \& Tsvilikhovskyi, 2014; Holopura et al., 2015).

Так, Ig, які поступають у шлунково-кишковий тракт теляти 3 молозивом матері, зв'язуються на поверхні ентероцитів за допомогою Fc-фрагменту власної молекули з білковим рецептором АМ, утворюючи відповідний комплекс Ig-рецептор. Завдяки інтенсивним процесам піноцитозу у новонароджених тварин, які обумовлені рядом факторів, у т. ч. низькою в'язкістю плазматичної мембрани (Tsvilikhovskyi, 1998; Maryniuk et al., 2014), комплекс Ig-рецептор у складі ендоцитозного пухирця транспортується через клітину в кров теляти.

Утворюючи комплекс Ig-рецептор білки плазмолеми ентероцитів, разом з імуноглобуліном, у складі ендоцитозного пухирця транспортуються в кров тварини, що призводить до зменшення їх кількості в мембрані. Динаміка цього процесу дуже добре проглядається у новонароджених телят контрольної групи вже на 6-у годину їх життя (див. рис. 1).

В той же час, застосування новонародженим телятам препарату - “Мембраностабіл”, що являє собою макрокапсули з фосфоліпідного бішару, які наповнені водорозчинними формами вітамінів А та Е, стабілізує плазмолему ентероцитів i, можливо, сприяє транскрипції відповідних генів з послідуючою стимуляцією синтезу рецепторних білків та включенням їх у мембрану. Відповідні дані щодо участі вітаміну А в процесах стимуляції синтезу мембранних білків на генетичному рівні є (Schägger \& von Jagow, 1987; Ross \& Ternus, 1993). Крім того, деякі автори вказують, що дефіцит вітаміну А в раціоні тільних корів приводить до абортів і порушення розвитку плода, затримання розвитку плаценти, зниження життєздатності телят i захворювання їх на диспепсію, яка розвиваються внаслідок порушення синтезу специфічних глікопротеїнів в ентероцитах (Bondi, 1987).

\section{Висновки}

На основі отриманих нами даних можна стверджувати, що білки 3 молекулярними масами 37, 40 та 43 кДа плазмолеми ентероцитів порожньої кишки великої рогатої худоби в процесі постнатального онтогенезу піддаються значним змінам. На наш погляд, показники експресії цих білків у плазмолемі ентероцитів порожньої кишки новонароджених телят за умов застосування препарату "Мембраностабіл" відображають суттєві зміни в мембранному травлені та транспорті речовин у тонкому кишечнику в перші дні постнатального онтогенезу. Отримані нами дані дозволяють висловити думку про позитивний вплив препарату "Мембраностабіл" на формування колострального імунітету та запобігання розвитку розладів травлення у новонароджених телят. 
Перспективи подальших досліджень У перспективі будуть продовжені дослідження впливу препарату “Мембраностабіл" на білки інших фракцій плазмолеми ентероцитів порожньої кишки новонароджених телят.

\section{References}

Bondi, A.A. (1987). Animal Nutrition. Chichester, John Wiley \& Sons.

Holopura, S.I., \& Tsvilikhovskyi, M.I. (2014). Korektsiia vmistu zahalnoho bilka ta sechovyny $\mathrm{v}$ syrovattsi krovi novonarodzhenykh teliat u period formuvannia kolostralnoho imunitetu. Visnyk Poltavskoi Derzh. ahrarnoi akademii, 3, 95-97. doi: 10.31210/ visnyk2014.03.18 (in Ukrainian).

Holopura, S.I., Maryniuk, M.O., \& Tsvilikhovskyi, M.I. (2017). Ekspresiia imunoretseptornykh proteiniv u plazmolemi enterotsytiv novonarodzhenykh teliat $\mathrm{u}$ period formuvannia kolostralnoho imunitetu. Biolohiia tvaryn, 19(2), 16-22. doi: 10.15407/ animbiol19.02.016 (in Ukrainian).

Holopura, S.I., Tsvilikhovskyi, M.I., Zamanbekov, N.A., \& Kaziiev, Zh.I. (2015). Rol bilkiv transferynovoi fraktsii syrovatky krovi u formuvanni kolostralnoho imunitetu u novonarodzhenykh teliat. Naukovyi visnyk NUBiP Ukrainy, 51-57. http://nbuv.gov.ua/UJRN/nvnau_vet_2015_221_11 (in Ukrainian).

Jones, E.A., \& Waldman, T.A. (1972). The mechanism of intestinal uptake and transcellular transport of $\mathrm{IgG}$ in the neonatal rat. J. Clin Invest, 51(11), 2916-2927. doi: 10.1172/JCI107116.

Kurtiak, B.M., \& Yanovych, V.H. (2004). Zhyrorozchynni vitaminy u veterynarnii medytsyni i tvarynnytstvi. Lviv: Triada plius (in Ukrainian).
Maryniuk, M.O., Holopura, S.I., Yakymchuk, O.M., Nemova, T.V., \& Tsvilikhovskyi, M.I. (2014). Riven kolostralnoho imunitetu i rozvytok rozladiv travlennia $\mathrm{u}$ novonarodzhenykh teliat. Veterynarna medytsyna Ukrainy, 5, 21-23. http://nbuv.gov.ua/UJRN/ vetm 201459 (in Ukrainian).

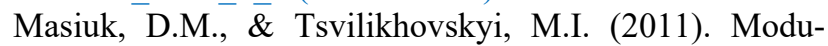 liatsiia ekspresii fc- $\gamma$-retseptoriv enterotsytiv Velykoi rohatoi khudoby u plodovyi period. Naukovi pratsi PF NUBiP Ukrainy "KATU" seriia "Veterynarni nauky", 139, 222-227 (in Ukrainian).

Morozkina, T.S., \& Mojsejonok, A.G. (2002). Vitaminy. Minsk: Asar, 58-63 (in Russian).

Ross, C., \& Ternus, M.E. (1993). Vitamin A as a hormone: recent advances in understanding the actions of retinal, retinoic acid and beta carotene. J. Am. Diet. Assoc., 93, 1285-1290. doi: 10.1016/00028223(93)91956-q.

Schägger, H., \& von Jagow, G. (1987). Tricine-sodium dodecyl sulfate-polyacrylamide gel electrophoresis for the separation of proteins in the range from 1 to 100 kDa. Analytical Biochemistry, 166(2), 368-379. doi: 10.1016/0003-2697(87)90587-2.

Suraj, P.F., Buzhin, A.A., Jaroshenko, F.A., \& Ionov, I.A. (1997). Zhirorastvorimye vitaminy. Cherkasy (in Russian).

Tsvilikhovskyi, M.I. (1998). Bilky plazmatychnoi membrany epiteliiu tonkoho kyshechnyka velykoi rohatoi khudoby: avtoref. dys. doktora biol. nauk: spets 03.00.04 - biokhimiia. Kyiv, NAU. Kyiv (in Ukrainian).

Tsvilikhovskyi, M.I., Maryniuk, M.O., Hololpura, S.I., Avdieieva, L.Iu., Nemova, T.V., Yakymchuk, O.M., \& Zhukotskyi, E.K. (2014). Veterynarnyi preparat "Membranostabil". Patent na korysnu model № 92841. Podano 13.03.2014, Opub. 10.09.2014, Biul. № 17 (in Ukrainian). 